
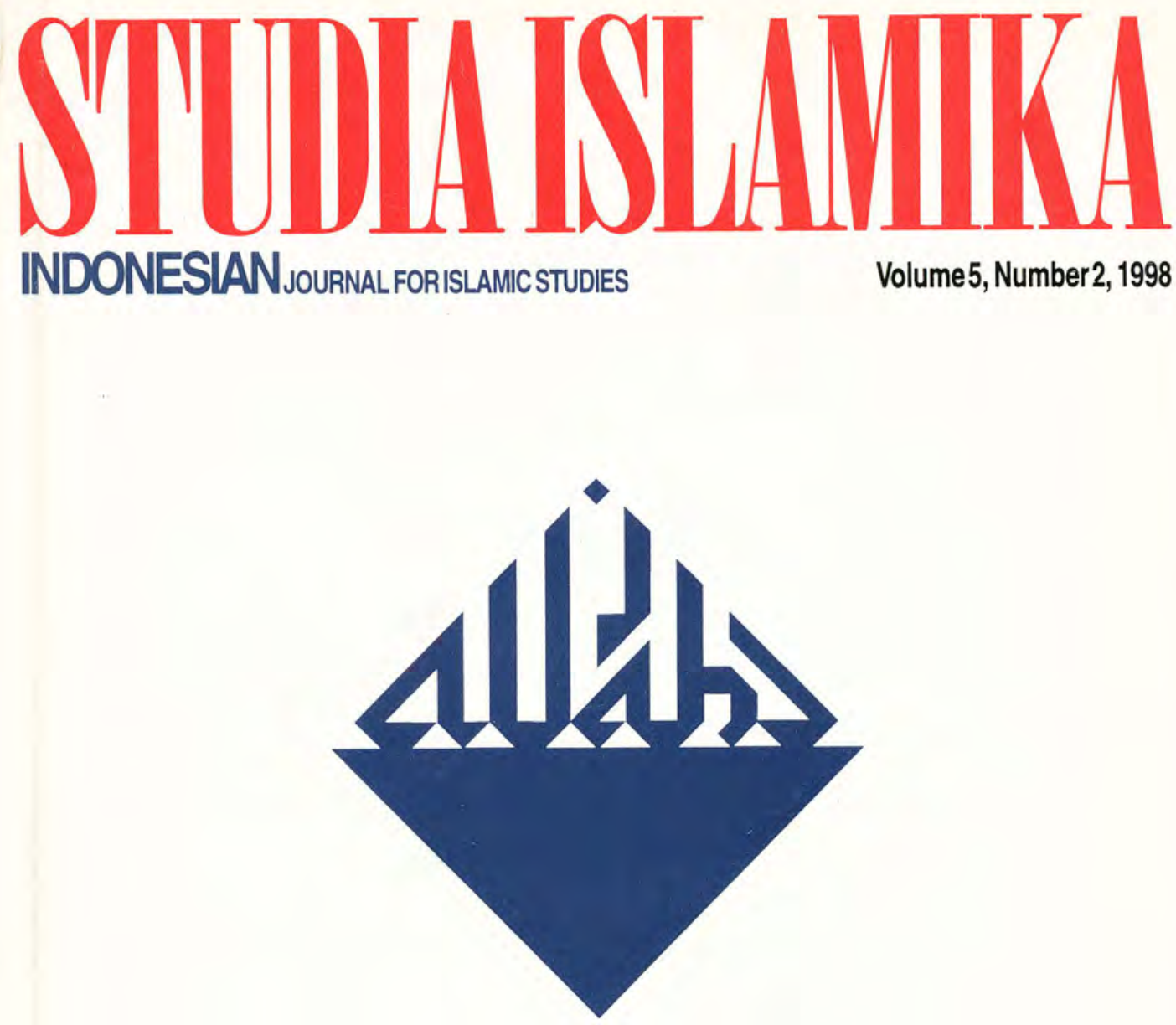

PIILgimages ANd Local ISLAM ON JAVA Huub de Jonge

MAḤFÛZ AL-TIRMISî (D. 1338/1919): AN INTELLECTUAL BIOGRAPHY Abdurrahman Mas'ud

Islam Observed: The CASE of Contemporary Malaysia Laurent Metzger

"The Clash of Civilization":

A PROgnosis OF the FUtURE OR THE LURE OF the PAST

Taufik Abdullah 


\section{SIIIDAISLAIIIKA \\ Indonesian Joumal for Islamic Studies \\ Vol. v, no. 2, 1998}

EDITORIAL. BOARD:

Harun Nasution

Mastuhu

M. Quraish Shihal

A. Aziz Dahlan

M. Satria Effendi

Nabilah Lubis

M. Yunan Yusuf

Komaruddin Hidayat

M. Din Syamsuddin

Muslim Nasution

Wahib Mu'thi

EDITOR-IN-CHIEF:

Azyumardi Azra

EDITORS:

Saiful Mujani

Hendro Prasetyo.

Johan H. Meuleman

Didin Syafruddin

Ali Murhanif

Assistants to THE EdTOR:

Arief Subhan

Oman Fathurrahman

Heni Nuroni

ENGlish Language AdVISOR:

Donald Potter

ARABIC LANGUAGE Advisor:

Nursamad

Cover Designer:

S. Prinka

STUDIA ISLAMIKA (ISSN 0215-0492) is a journal published quarterly by the Institut Agama Islam Negeri (IAIN, the State Institute for Islamic Studies) Syarif Hidayatullah, Jakarta. (STT DEPPEN No, 129/SK/DITJEN/PPG/STT/1976) and sponsored by the Department of Religious Affairs of the Republic of Indonesia. It specializes in Indonesian Islamic studies, and is intended to communicate original researches and current issues on the subject. This journal warmly welcomes contributions from scholars of related disciplines.

All articles published do not necessarily represent the views of the journal, or other institutions to which it is affiliated. They are solely the views of the authors. The articles contained in this journal have been refereed by the Board of Editors. 


\title{
Wacana Baru Islam-Jawa
}

\begin{abstract}
M.C. Ricklefs, The Seen and Unseen Worlds in Java: History, Literature and Islam in the Court of Pakubwiana II 1726-1749, (Honolulu: Asian Studies Association of Australian in association with Allen \& Unwin and University of Hawail Press, 1998).
\end{abstract}

Abstract: As far as the Indonesian studies are concerned, Java has become the most celebrated field of study. There are a great number of scholarly works, from various points of view, concerning the Javanese society and culture. The book by M.C. Ricklefs, which is under discussion, can be said to bave specific importance. This is especially due to the fact that its main discussion, the revival of Javanese culture in the eighteenth century, is a subject which has been so far neglected from scholarly attention. Moreover, this importance also lies in the fact that Islam is conceived as having a central position in that Javanese cultural revival. It follows that this book makes different assumptions from previous scholarly works, in particular those from the colonial time, which tend to regard Islam as always being in conflict with, and therefore having no significant impact upon Javanese culture and society.

The reign of Pakubuwana II (1726-1749) of the Mataram Kingdom witnessed the Javanese cultural revival, which proceeded in line with the Islamic resurgence, in particular the neo-Sufi movement. During this period, Java and the Archipelago at large had intensive contact with the Islamic heartland in the Middle-East, through which many Indonesian 'ulamâ' (Muslim scholars) emerged as transmitters introducing Middle-East Islamic thought and development to the Indonesian Muslims. In the context of Java, this Islamic development then gave rise to the cultural revival, which was to be seen in, among other things, many Javanese literature texts (suluk and babad) derived from this period that were written within the Javanese royal circle. Thus Carita Iskandar, Kitab Usulbiyah, and Serat Cabolek, some of the texts discussed, are conceived as "Islamic Javanese texts" in which Islamic values constituted the main substance.

Written within the Javanese royal circle, Ricklefs emphasizes, the Javanese texts mentioned of course dwell on the existing political conditions of the Javanese Kingdom in the period concerned. Pakubuwana II, the Mataram 
ruler, had to deal at that time with political problems resulting both from political intrigues among royal courtiers and notably from the increasing power of the Dutch trade organization (VOC). In this respect, the rise of Javanese literature can be said to be a type of cultural response by the Javanese royal elite towards the problem on the basis of both Islamic development and Javanese heritage from pre-Islamic time. Being a cultural response, the texts mentioned are therefore of political significance, in that they were directed to give political legitimization to the ruler who faced ideological queries. Thus it can be understood that the Javanese texts, more especially Carita Iskandar, emphasize an heroic image of figure Iskandar Zulkarnain, who is described as an ideal Muslim ruler.

The above political dimension becomes even more apparent in the other Javanese text studied, Suluk Garwa Kencana. In this text, the Javanese political ideas, especially those concerning the rulership, are clearly formulated. This text sets forth, for instance, some prerequisites for becoming an ideal ruler, such as performing all Islamic duties and more importantly becoming a Sufi to be able to gain supernatural knowledge from the ultimate Reality. Thus in this Suluk, the Sufi-King (Raja-Sufi) is a Javanese formulation of an ideal ruler. This idea is clearly derived from both Islamic Sufism and the Javanese heritage, especially the boddhisarwa idea from Hindu-Buddhist tradition. With the same token, it can also be said here that Islam in Java is always embodied in the formulation embedded in the pre-Islamic Javanese culture.

The idea of Sufi-King is clearly addressed to Pakubuwana II. He was expected to be an ideal ruler of the Mataram Kingdom which had faced serious political problems following the death of Sultan Agung in 1646. However, as explained in this book, Pakubuwana II seemed not to be capable of making bimself the Sufi-King as expected. The existing realpolitik in Java during the period concerned was too complicated and powerful for a Sufi-King whose life was more otherworldly in orientation. Thus in the end Pakubuwaha II failed to meet the Javanese cultural expectation ascribed to bim. He not only released his throne to Sunan Kuning, the Javanese rebel -which situation could only be solved with VOC intervention - but more importantly he left the Mataram Kingdom to be divided into two and then four independent kingdoms under the protection and the authority of VOC.

This failure then led to the idea of a Sufi.King becoming questionable, and above all ended the harmonious Islam-Java relationship. Thus in the following century conflict and tension between Islam and Javanism, and between santri and abangan, formed a dominant discourse in the history of Islam in Java. 


\section{Wacana Baru Islam-Jawa}

M.C. Ricklefs, The Seen and Unseen Worlds in Java: History, Literature and Islam in the Court of Pakubuwana II 1726-1749, (Honolulu: Asian Studies Association of Australian in association with Allen \& Unwin and University of Hawaii Press, 1998).

خلاصة: لقد صارت جاوا أكثر البخالات إثنارة لإجراء الدراسة في اندونيسيا،

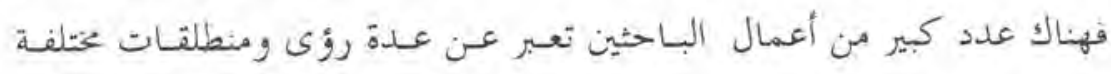

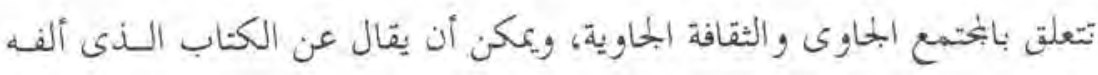

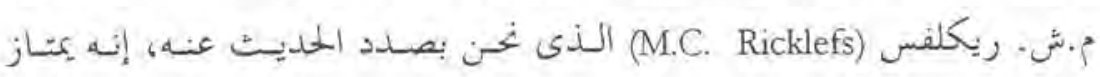

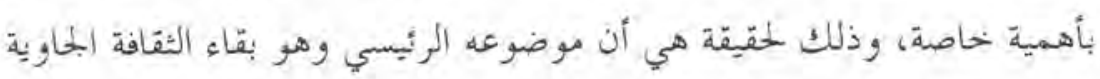

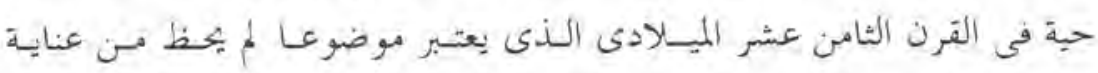

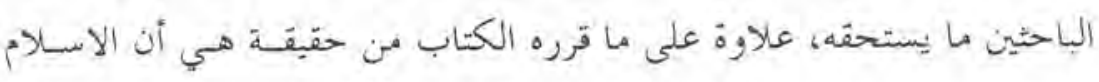

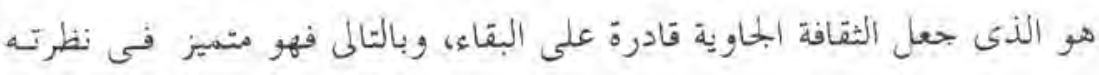

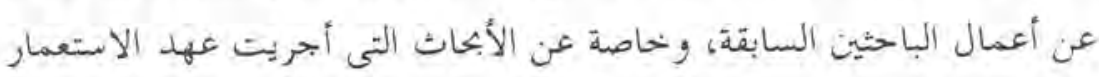

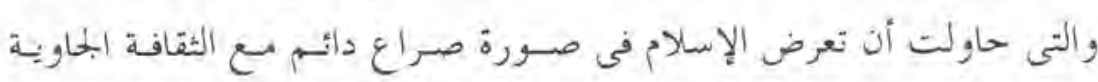

$$
\text { والجتمع الجاوي، ولذلك ليس لتأثير الاسلام عليها أئية أهمية. }
$$

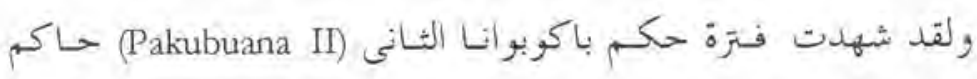

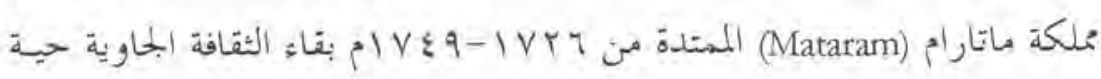

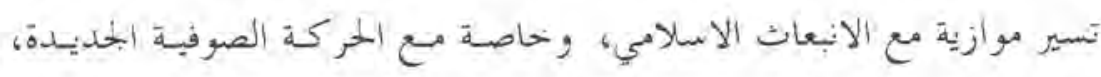

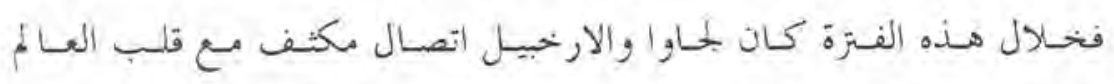

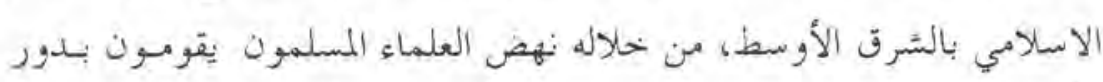

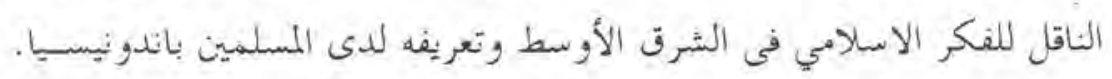

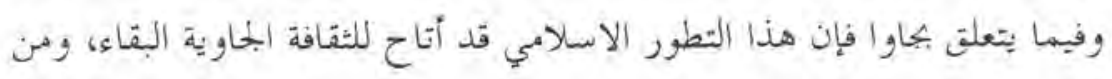


بين الشواهد التى تشبت هذه المقيقة ما نطقت به نصوص الأدب الجاوي الذى أسموه بال"سلوك" (buluk) أو الـ"باباد" (babad)، وهي نصـوص يرجسع تاريخها إلى هذه الفترة وكتبت من خلال الدائرة الملكية. فـالثصوص الواردة في كـل من كتاب شاربيًا اسكندر (Carita Iskandar) وكتاب أصولبية (Usulbiyah) وكذلك سيرات شيبوليك (Serat Cibolek)، مس بـين النصوص التى عالجها الكتـاب، تعـد نصوصـا جاويـة إبـلامية حبـث تشـكل القيسم الاسبلامية فـى جوهرها المضمون الرئيسي. وإذن، هكنا أكيد ريكلفس، فبان كتابـة نّلك النصـوص الجاويسة المذكورة داخل الدائرة الملكية تيل بالطبع على مـا عليه المملكة الجاويـة فيهـا

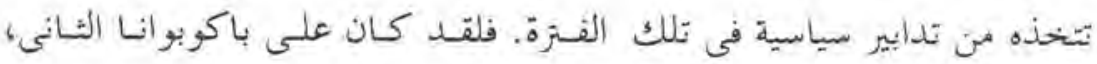
حاكم عُلكة ماتار ام، أن يعاج المشاكل السياسية الناجمة عن المؤامرة التى يقَّوم بها الحاشية الملكية وثوبع نفوذ الشـركة الملكية الفولنديـة (VOC). وفى هـذا

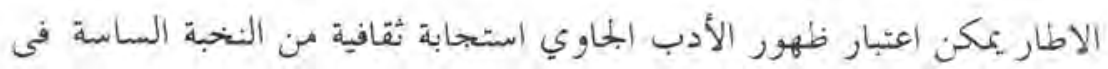

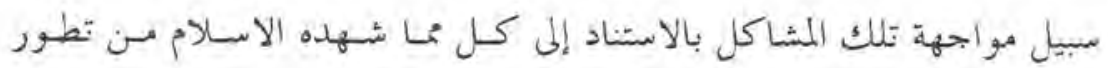
والتزاث الجاوي المثوارث عليه من عهبد مـا قبل الاسـلام، وركونها ابستجابة ثقافية فإن للنصوص المذكورة أهمية سياسية مسن حبـث أنها وجهبت لإعطلاء سند شرعي للحاكم الـذى كان في أمس الحاجـة إلى ايديولوجيـة سياسية.

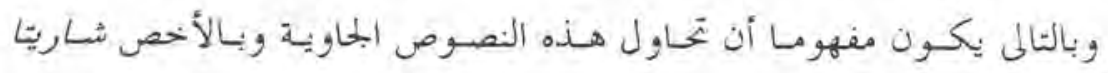

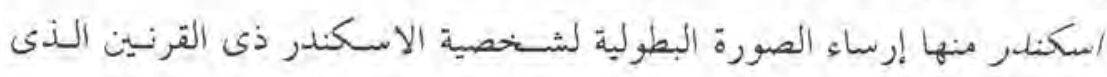
يعتقد أنه الخاكم المسلم حقا.

ويظهر هذا البعد السياسي واضحا فى النصوص الأخرى التى عالجها

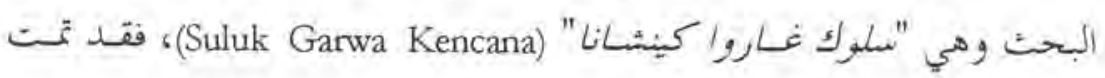


صياغة الأفكار السياسية فيها بشكل واضح خاصة فيمـا تتعلق بنظبام الخكسم، حيث صورت على نبيل المثال الشروط الـلازم توافرهـا ليكون ألمرءء حاكمـا حقا، ودلك بأداء جميع الواجبات الدينية وأهمها أن بصير الحاكم صوفيا حتى

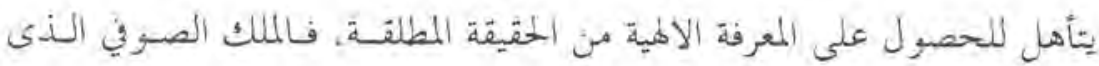

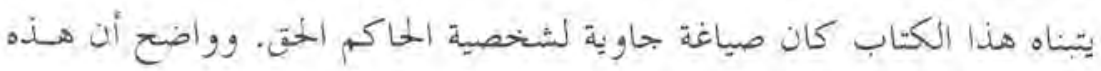
الفكرة مأخودة من التصوف الاسلامى والتراث الجاوي وبالأصع فكرة "بونى

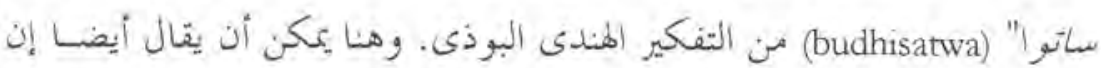
الاسلام فى جاوه يتجسد دائما في الصياغـة التى تنطمسر فيها ثقافة مـا قبل الاسلام الخحاوية. وقد كان الملك باكوبو انا الثانى هو المشار إليه بفكرة الملك الصسوقيه

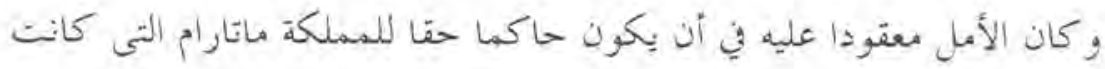

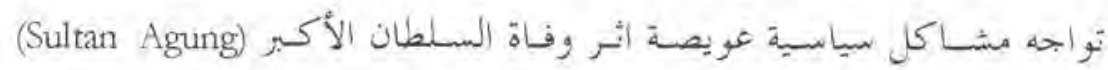

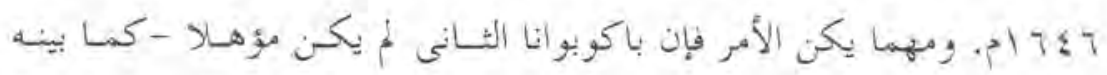
الكتاب - لإعداد نفسه أن يكون ملكا صوفيا، قـالراقع السياسي في الفـترة

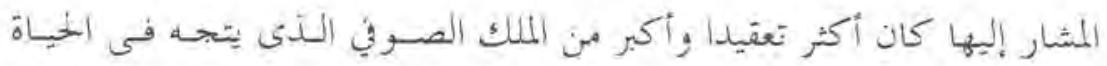

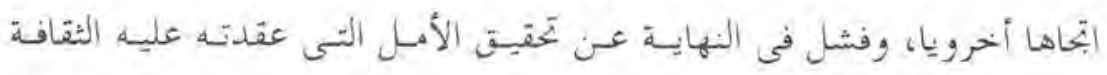

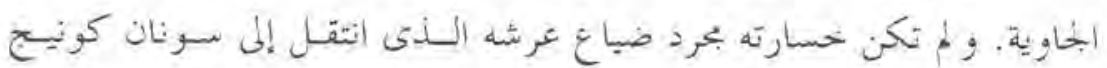

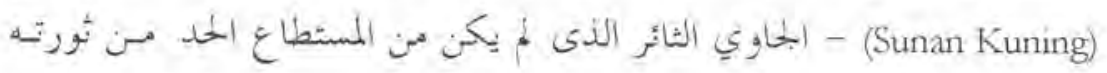

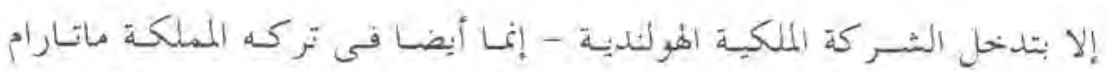

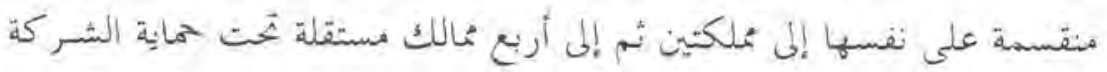
الملكية الهولناية و سلطتها. 
B uku ini menyajikan pembahasan tentang periode sangat penting dalam sejarah tanah Jawa, tapi terabaikan dari pemahaman kita, yakni paruh pertama abad ke-18 atau tepatnya masa kekuasaan Pakubawana II (1726-1749). Harus diakui, perkembangan di Jawa abad ke-17, ketika Mataram mencapai kejayaan di bawah Sultan Agung (1613-1646), tampak lebih kuat mendominasi pengetahuan kita tentang sejarah Jawa. Begitu pula hal yang sama berlaku pada perkembangan di abad ke-19. Periode ini, selain menyaksikan berbagai peristiwa pemberontakan, juga mencatat revivalisme Islam sebagai kekuatan politik dan intelektual, yang berkoeksiden dengan kebangkitan budaya Jawa. Beberapa kajian sebelumnya bahkan cenderung berkesimpulan bahwa abad ke-19 merupakan periode di mana "budaya Jawa" mengalami proses perumusan dan pelembagaan. ${ }^{1}$

Dalam buku ini, Ricklefs-seorang yang memang telah lama meng. abdikan dirinya dalam studi sejarah Jawa-mengedepankan kesimpulan berbeda. Menurutnya, perumusan dan pelembagaan budaya Jawa berlangsung pada masa kekuasaan Pakubuwana II di abad ke18 , periode yang menjadi sasaran pembahasan buku ini. Dia dalam hal ini berpendapat, pada masa itulah istana kerajaan, sebagai basis reproduksi nilai dan makna, mengetengahkan rumusan sistem budaya Jawa, lebih khususnya bidang politik. $\mathrm{Hal}$ ini bisa dilihat pada wacana yang muncul dalam teks-teks sastra Jawa yang lahir dari periode itu, di mana isu-isu politik dan agama, terutama berkaitan dengan usaha sekitar legitimasi kerajaan Jawa, menjadi sangat dominan. Melalui karya-karya sastra ini, konsep tentang raja dan kekuasaan, serta konsep-konsep lain yang berhubungan dengan politik, memperoleh formulasinya yang tegas serta menjadi dasar bangunan politik kerajaan Jawa.

Dalam proses kebangkitan ini, hal terpenting yang dicatat Ricklefs adalah besarnya pengaruh Islam pada wacana yang berkembang. Dalam kajiannya terhadap teks-teks tersebut, seperti akan dijelaskan nanti, Islam membentuk satu substansi utama dalam proses kebangkitan budaya Jawa. Bersama dengan tradisi Jawa pra-Islam yang bersifat Hindu-Budhis, Islam memberikan landasan nilai dan etik bagi bangunan sistem budaya Jawa yang dirumuskan, Di sini, Islam dan ke-Jawa-an (Kejawen), yang kerap dipandang sebagai bertentangan, justru memperlihatkan satu kesesuaian yang harmonis. Keduanya sama-sama membentuk satu paradigma baru bagi kebangkitan budaya Jawa. Dengan ungkapan lain, perumusan budaya Jawa berlang- 
sung di tengah suasana di mana Islam telah mengalami perkembangan dan pelembagaan yang intensif dalam kehidupan masyarakat.

\section{Latar Belakang Sosial-Politik}

Pakubuwana II naik ke singgasana kektasaan di saat kraton Mataram tengah dilanda berbagai persoalan politik yang berkepanjangan. Sepeninggal Sultan Agung, sebagaimana diketahui, Mataram memang terus-menerus menghadapi berbagai gejolak politik yang membawa kerajaan tersebut mengalami kemunduran. Di banyak wilayah telah terjadi berbagai pemberontakan, menyusul sikap dan kebijakan politik penguasa dinasti yang cenderung tidak populer di kalangan masyarakat. Kondisi ini menjadi semakin buruk bersamaan dengan kekuasaan VOC di Jawa yang saat itu telah menjadi satu kekuatan politik sangat menentukan, VOC bisa secara langsung melakukan intervensi dalam tubuh istana, termasuk menentukan penguasa yang naik ke singgasana kekuasaan. Pada masa menjelang naiknya Pakubuwana II, hubungan Mataram-VOC ini bahkan semakin subordinatif. Legitimasi politik raja-raja Mataram lebih didasarkan pada pengakuan VOC.

Pakubuwana II naik takhta di Mataram menggantikan ayahnya, Amangkurat IV (1719-1726), yang konon meninggal karena diracun. Ia waktu itu berusia 16 tahun, usia yang terbilang sangat muda terutama bila mengingat besarnya persoalan politik dan ekonomi yang harus ditanggung. Pengakuan VOC, yang diberikan tidak lama setelah ia naik tahta, segera disusul kewajiban membayar hutang dalam jumlah sangat besar yang ditinggalkan penguasa sebelumnya, yakni sejak Pakubuwana I(1704-1719). Melalui sebuah kesepakatan yang dibuat, yang sekaligus merupakan jaminan dukungan politik VOC bagi Mataram, Pakubuwana berkewajiban membayar 10.000 real seriap tahun dalam jangka waktu 20 tahun. Pembayaran ini untuk menutupi hutang kerajaan serta bunganya. Selain itu, dia juga diharuskan membayar 15.600 real setiap tahun untuk membayar garnisun VOC di Kartasura, dan 1.000 koyan ( 1.700 metrik ton) beras setiap tahun selama lima puluh tahun.

Kesepakatan dengan VOC ini memang berhasil memberi jaminan politik bagi kekuasaan Pakubuwana II. Ia di awal kekuasaanya tidak menghadapi berbagai gejolak politik yang berarti, khususnya yang mempertanyakan legitimasi kekuasaan yang baru dipegangnya. Satusatunya gerakan dilakukan Cakraningrat IV (1718-1746) di Madura, 
yang menolak mengakui keberadaan Mataram dan lebih memilih berada di bawah kekuasaaan VOC. Tetapi itu tidak bertahan lama, karena Cakraningrat IV segera berdamai dengan Mataram setelah bisa mempersunting saudara perempuan Pakubuwana II. Jadi, kesepakatan dengan VOC telah membawa Pakubuwana II berhasil menduduki puncak kekuasaan tanpa didahului pemberontakan politik seperti dialami raja-raja Mataram sebelumnya, Pakubuwana I dan Amangkurat IV, yang kemudian dikenal dengan Perang Suksesi Jawa.

Namun tidak demikian halnya dengan kehidupan di dalam istana. Pakubuwana II justru dihadapkan pada sejumlah persoalan yang bersumber dari intrik politik para pejabat senior kerajaan, yang memang menduduki posisi sangat kuat dalam konstelasi politik Mataram. Mereka menjadi tokoh sentral yang berpengaruh besar bagi hampir setiap kebijakan politik oleh Pakubuwana II. Setidaknya ada tiga tokoh penting yang perlu diberi catatan di sini: Ratu Pakubuwana, nenek Pakubuwana II yang berpengaruh besar dalam kebangkitan budaya dan tradisi intelektual Jawa saat itu, khususnya melalui karyakarya sastra. Selain itu, Ratu Pakubuwana juga sangat berpengaruh besar dalam menentukan kebijakan politik kerajaan. Bersama dengan Ratu, juga ada seorang yang memiliki perhatian besar baik di bidang politik maupun sastra, yakni Demang Urawan, kemudian terkenal dengan Pangeran Purbaya. Dia adalah saudara istri raja Pakubuwana II, Ratu Kencana.

Tokoh lain yang lebih berpengaruh secara politik adalah Danureja. Dia adalah seorang Patih, wakil raja untuk menangani berbagai urusan kerajaan, termasuk hubungan dengan VOC. Posisi Danureja sangat sentral dalam kraton Mataram saat itu, termasuk dalam upayanya meyakinkan pihak VOC tentang kekuasaan Pakubuwana II. Maka pada awal kekuasaan Pakubuwana II, dia secara definitif menentukan hampir semua keputusan kerajaan. Besarnya pengaruh politik Danureja ini didukung pengalaman politik yang luas di Mataram. Dia muncul pertama kali pada masa Pakubuwana I, yang menempati posisi sebagai Patih Kedua pada 1710. Pada 1719 dia ditahan VOC karena diduga terlibat dalam pemberontakan Pangeran Purbaya dan Blitar. Tetapi dia segera dibebaskan dan tetap ditempatkan pada posisi penting di kerajaan. Bahkan, dia setelah itu dipercaya mewakili kerajaan untuk VOC di Semarang. Kekuasaan dan pengaruh politik Danureja ini terus bertahan pada masa Amangkurat IV, dan berlanjut pada Pakubuwana II. 
Ketiga tokoh penting itulah yang sangat menentukan format politik dan budaya Mataram selama di bawah kekuasaan Pakubuwana II. Fenomena ini tentu saja merupakan bukti kelemahan Pakubuwana II dalam melakukan kontrol politik di kerajaan. Kraton saat itu semakin berkembang menjadi pusat persekongkolan di antara ketiga tokoh penting di atas, bersama beberapa tokoh politik lain yang ikut terlibat dalam permainan kekuasaan di kerajaan. Konflik politik ini sangat berkaitan dengan keberadaan VOC sebagai pemegang kekuasaan riil di Jawa, yang bisa memberi jaminan militer kepada pihakpihak tertentu yang dikehendaki. Sehingga, seperti akan dijelaskan nanti, konflik yang terjadi sedikit banyak diwarnai pertentangan antara mereka yang menghendaki keterlibatan VOC di istana Mataram dan yang menghendaki sebaliknya.

Dalam kondisi demikianlah Pakubuwana II menjalankan kekuasaanya di kerajaan Mataram. Praktek-praktek politik Pakubuwana II ini secara rinci akan dibahas di bagian selanjutnya. Namun hal penting dicatat di sini, kondisi politik Mataram saat itu telah berpengaruh besar bagi kegagalan Pakubuwana II untuk bisa mengembalikan Mataram kembali sebagai sebuah kerajaan besar seperti masa sebelumnya. Di bawah Pakubuwana II, persoalan-persoalan politik dan legitimasi raja menjadi semakin menghadapi gugatan dari pelbagai pihak, yang kemudian berujung pada terjadinya perpecahan di kerajaan. Pakubuwana II dalam hal ini adalah raja terakhir yang masih menyandang simbol kesatuan Mataram di kraton Kartasura. Setelah itu, Mataram mengalami perpecahan yang permanen-tentu saja melalui campur tengan VOC-menjadi dua kerajaan, Yogyakarta dan Surakarta, di samping dua kerajaan lain yang memiliki kekuasaan lebih kecil.

Namun demikian, justru dalam kondisi politik seperti di atas budaya Jawa mengalami perkembangan pesat. Kraton menjadi basis kebangkitan karya-karya sastra, yang selanjutnya memberi kontribusi penting bagi kebangkitan budaya Jawa. Ratu Pakubuwana muncul sebagai seorang yang mempelopori penulisan karya-karya sastra, khususnya yang berisi sekitar masalah politik dan legitimasi agama terhadap kerajaan. Wacana dominan dalam karya-karya sastra tersebut sangat menekankan kebesaran kerajaan dan keagungan pribadi sang raja. Karya-karya tersebut memang ditulis dalam rangka memberi justifikasi terhadap penguasa Mataram yang terus-menerus dilanda masalah legitimasi. 


\section{Islam dalam Teks Sastra Jawa}

Telah disinggung sebelumnya, perkembangan budaya Jawa berlangsung ketika Islam tengah mengalami satu kebangkitan, khususnya melalui gerakan neo-Sufisme yang semakin memperloleh tempat di masyarakat. Abad ke-17 dan 18 dalam sejarah Nusantara memang menyaksikan kuatnya arus gerakan neo-Sufis, yang berkembang melalui proses transmisi intelektual oleh para ulama Nusantara yang belajar di Timur Tengah, yakni Makkah dan Madinah. Melalui satu jaringan intelektual, para ulama memperkenalkan pemikiran Islam yang tengah berkembang di Timur Tengah kepada masyarakat Mus$\lim$ Nusantara. Di Melayu-Nusantara, di antara para ulama yang bertanggung jawab bagi lahirnya gerakan neo-Sufis ini adalah Nur al-Din al-Raniri, 'Abd al-Ra'uf al-Sinkili, dan Muhammad Yusuf al-Maqassari. Pemikiran mereka selanjutnya dilanjutkan para ulama lain di abad ke-18, seperti 'Abd al-Shamad al-Palimbani, Muhammad Arsyad al-Banjari, dan sebagainya. ${ }^{2}$

Dalam konteks sejarah Jawa, kebangkitan Islam di atas antara lain bisa dilihat melalui karya-karya sastra kraton yang ditulis pada periode ini. Seperti akan dibahas berikut ini, karya-karya sastra Jawa dari abad ke-18 ini, teparnya masa kekuasaan Pakubuwana II, menampilkan nuansa keislaman yang sangat kuat. Islam dalam karya-karya tersebut menempati posisi sangat penting, sebagai basis utama dari wacana yang muncul yang berkaitan dengan budaya dan politik Jawa. Dalam hal ini terdapat tiga karya sastra Jawa, dibahas bab 2, yang dinilai telah menampilkan kuatnya pengaruh Islam dalam budaya Jawa: Carita Iskandar, Carita Yusuf, dan Kitab Usulbiyah. Ketiga karya tersebut diidentifikasi sebagai buah karangan (ingkang ayasa) Ratu Pakubuwana, seorang yang memang dikenal memiliki kekuatan spiritual sangat besar di lingkungan kraton Jawa saat itu.

Karya-karya sastra di atas, seperti terlihat dari judulnya, memang memperlihatkan kuatnya pengaruh Islam, atau lebih tepatnya tradisi sastra yang sudah melembaga di dunia Muslim. Dua teks yang disebut pertama, Carita Iskandar dan Carita Yusuf, adalah contoh yang jelas dalam hal ini. Karya tersebut diadopsi dari karya yang sama yang sudah beredar baik di Nusantara sendiri, khususnya di Melayu, maupun dari tradisi Islam di negara Muslim lain. Dalam Carita Iskandar secara tegas dikatakan bahwa teks tersebut ditulis berdasarkan teks serupa yang sudah beredar di bagian Dunia Melayu lainnya, yakni Serat Iskandar Zulkarnain. ${ }^{3}$ Begitu pula dengan Carita Yrusuf. Dalam teks tersebut bahkan dikatakan bahwa cerita ini didasarkan pada kisah 
dalam al-Qur'an mengenai Nabi Yusuf. Jadi, dari fakta ini saja, bisa diasumsikan bahwa karya-karya sastra di atas, yang menjadi bukti kebangkitan budaya Jawa, dikarang berdasarkan khazanah sastra dan tradisi intelektual Muslim.

Hal ini bahkan menjadi lebih jelas bila kita memperhatikan isi utama teks-teks tersebut. Teks Carita Iskandar berisi tentang kisah Iskandar Zulkarnain, yang digambarkan sebagai seorang penguasa Muslim ${ }^{4}$ yang menaklukkan dunia dari Timur hingga ke Barat (dari masyrik sampai ke maghrib). Bersamaan dengan itu, dia juga digambarkan sebagai yang bertanggung jawab melakukan Islamisasi di banyak wilayah di dunia. Singkatnya, Iskandar Zulkarnain adalah seorang pemimpin Muslim yang senantiasa memperoleh bimbingan Tuhan. Dan dengan kekuasaannya yang besar sebagai raja dunia, dia telah membawa kemenangan bagi Islam. Jadi, penekanan utama teks ini terletak pada kebesaran seorang raja Muslim yang digambarkan sebagai pemimpin yang ideal. Begitu pula hal yang sama terdapat dalam teks Carita Yusuf. Seperti halnya Iskandar, teks ini juga bercerita tentang kisah seorang pemimpin Muslim, Nabi Yusuf, yang berkuasa secara adil di bawah bimbingan wahyu Tuhan.

Penuturan kisah kedua tokoh Muslim dalam dua teks tersebut, memberi kesan kuat bahwa kraton Jawa saat itu tengah mengalami proses intensifikasi keislaman yang sangat kuat. Wacana yang muncul dalam dua teks di atas jelas-jelas memperlihatkan suasana kraton Jawa yang sangat akrab dengan tradisi dan budaya Muslim. Hal ini selanjutnya bisa dipahami bahwa pada periode pembahasan ini, abad ke-18, Nusantara memang semakin berkembang menjadi bagian integral dari dunia Islam (dar al-Islam). ${ }^{5}$ Dalam kasus Jawa, hal terakhir ini bisa dilihat terutama melalui teks Carita Iskandar. Tidak seperti teks-teks Jawa lain, teks Iskandar sangat populer di Nusantara. Di dunia Melayu, kisah Iskandar ini memperoleh apresiasi sedemikian luas dalam karya-karya sastra. ${ }^{6}$ Dalam teks Sejarah Melayu, misalnya, kisah Iskandar ini bahkan menempati posisi sangat istimewa. Ia mengisi bagian pertama pembahasan teks, sehingga kemudian disebut "episode Iskandar"? Semua bukti-bukti ini menujukkan bahwa Jawa saat itu, seperti wilayah-wilayah lain di Nusantara, telah berada dalam arus umum dunia Muslim yang tengah mengalami kebangkitan keagamaan.

Lebih dari itu, penting ditekankan, penuturan kisah dua tokoh Muslim di atas sekaligus bisa dilihat sebagai bukti hadirnya moda baru konseptualisasi masyarakat Jawa terhadap realitas, yang berba- 
sis pada kondisi historis di mana Islam semakin memperoleh akar yang kuat. Islam dalam hal ini menjadi dasar sebuah sistem nilai dan makna, yang berfungsi sebagai model untuk memberi pemaknaan terhadap kenyataan yang berlaku di tanah Jawa. Bila demikan halnya, dalam konteks politik, bisa diasumsikan bahwa kisah dua penguasa Muslim dalam dua teks di atas dengan sendirinya memiliki makna sangat berarti bagi kekuasaan Jawa. Dalam hal ini, kondisi politik kraton Jawa saat itu memang sangat berkepentingan menghadirkan seorang tokoh penguasa ideal-adil, bijaksana, sangat berkuasa, dan Islam-sebagai salah satu upaya memberikan justifikasi kultural terhadap kekuasaan Jawa yang terus dihadapkan pada masalah legitimasi politik.

Hal terakhir ini tampak sedemikian jelas pada fakta bahwa, seperti diungkap Ricklefs, penulisan dua teks di atas diklaim telah dilakukan dalam suasana serta dengan kekuatan supranatural, serta berada dalam kaitan erat dengan Sultan Agung, raja Mataram terbesar. Di bab pembuka dua teks ini, misalnya, dikatakan bahwa Ratu Pakubuwana, penulis dua teks (ingkang ayasa) yang menuturkan kisah dua penguasa Muslim, adalah seorang yang memiliki kekuatan spiritual. Dia, dengan kekuatan ini, menulis karya-karya sastra berdasarkan teks-teks Jawa serupa yang beredar pada masa Sultan Agung. Dan teks ini ditulis sebagai khazanah, sebagai pusaka, untuk Pakubuwana II, yang bisa memancarkan nilai-nilai spiritual bagi para keturunan keluarga kerajaan Jawa. Jadi, dua teks Jawa tersebut ditulis dalam rangka memberi kekuatan spiritual kepada raja Pakubuwana II, yang dilakukan dengan mengedepankan klaim keagamaan serta diletakkan dalam hubungan spiritual dengan Sultan Agung.

Sampai di sini, bisa dikatakan bahwa baik teks Carita Iskandar maupun Carita Yusuf memberi mitos peneguh kekuasaan kerajaan Jawa, yang dikedepankan dalam bentuk kisah-kisah legendaris seorang tokoh yang telah berakar dalam tradisi Muslim. Pembahasan dua teks tersebut memberi kesan kuat bahwa proses ingkang ayasa oleh Ratu Pakubuwana menyimpan hasrat menjadikan Islam terekspresikan dalam terma-terma budaya Jawa. Dalam dua teks di atas, hasrat tersebut masih hanya terbatas pada menghadirkan kisah-kisah legendaris raja-raja Muslim yang dinilai memiliki makna politik bagi kerajaan Jawa. Namun tidak demikian halnya dengan teks sastra Jawa lain yang dibahas kemudian, Kitab Usulbiyah. Teks ketiga yang dikarang Ratu Pakubuwana ini, juga dikenal Kitab Ngusulbiyah, mengetengahkan rumusan Islam yang lebih di-Jawa-kan (Javanized). Kisah 
mi'raj Muhammad dan pertemuannya dengan beberapa Nabi, yang menjadi inti pembahasan teks-sehingga ia dinilai sebagai analogi Jawa terhadap teks Qisas al-Anbiya-dituturkan dalam nuansà yang sangat akrab dengan suasana dan budaya Jawa.

Dalam salah satu pembahasannya, Kitab Usulbiyah misalnya menggambarkan bahwa Tuhan, Nabi Muhammad dan Nabi Isa-sebagai tokoh sentral dalam pembahasan teks-seakan berperilaku sebagai raja-raja Jawa. Nabi Isa disebut berbicara dalam bahasa Arab dan Jawa, dan Nabi Muhammad memakai mahkota kerajaan Jawa Majapahit, Dan topik diskusi di antara mereka banyak berkenaan dengan ajaran mistisisme yang umum terdapat dalam teks-teks sastra Jawa. Begitu pula hal yang sama terdapat dalam pemaparan teks tentang percakapan Nabi Isa dengan Muhammad, khususnya ketika Nabi Isa menyarankan Muhammad membangun sebuah istana ketika dia hijrah ke Madinah. Dalam teks tersebut, Madinah, tempat Nabi Muhammad membangun kraton, digambarkan mengacu pada kondisi tanah Jawa di mana kraton Kartasura dibangun; hutan lebat, dan dihuni banyak binatang luas, seperti singa, anjing, dan kerbau. Semua itu merupakan ciri-ciri utama tanah Jawa, bukan Madinah yang telah berkembang sebagai kota dagang.

Lebih dari itu, Kitab Usulbiyah ini tampak ditempatkan pengarangnya pada posisi yang sangat istimewa, bahkan melampaui dua teks sebelumnya. Di bagian awal dikatakan bahwa teks ini dikarang untuk menyempurnakan raja muda Pakubuwana II dengan mengedepankan ajaran-ajaran mistik tentang kesempurnaan. Selanjutnya, dikatakan bahwa teks ini merupakan anugrah kekuatan (sawab) yang memiliki pengaruh spiritual dan profan, baik berkaitan dengan isinya yang memang memiliki potensi demikian maupun pengarangnya yang selalu diberkahi Tuhan. Dikatakan, Ratu Pakubuwana ketika mengarang teks ini adalah seorang yang tengah mendekati kesempurnaan. Oleh karena itu, Kitab ini selanjutnya disejajarkan dengan al-Qur'an. Ia diklaim berisi firman Tuhan, dan berfungsi sebagai jimat yang membawa kemenangan dalam Perang Suci. Maka orang yang menulis Kitab ini disamakan dengan orang pergi haji ke Makkah atau membaca al-Qur'an seribu kali, dan yang menyimpannya akan dijaga tujuh ratus Malaikat. Dengan membaca Kitab ini, orang kafir bisa menjadi Muslim dan orang bodoh menjadi pintar.

Memperhatikan wacana ketiga teks di atas, tampak bahwa Islam memang memberi kontribusi penting dalam kebangkitan sastra dan budaya Jawa. Pembahasan ketiga teks di atas menunjukkan bukti 
kuat bagaimana Islam membentuk satu substansi penting dalam wacana yang berkembang. Namun, pada saat yang sama, arus panggilan budaya Jawa yang menghendaki pelestarian tradisi dan agama praIslam juga tampak sangat kuat. Dalam ketiga teks di atas tampak sedemikian besar hasrat kalangan kraton Jawa untuk menerima ajaran Islam sejalan dengan tingkat kemampuan adaptasi budaya mereka. Penjelasan berikut ini adalah untuk mengeksplorasi secara rinci titik kesesuaian antara Islam dan budaya Jawa, khususnya yang berkaitan dengan masalah-masalah politik.

\section{Raja-Sufi:}

\section{Konsep Penguasa Ideal}

Dari semua pembahasan di atas, terdapat kesan kuat bahwa posisi sentral raja dalam bangunan politik dan budaya Jawa merupakan wacana dominan dalam ketiga teks Jawa yang telah dikaji. Munculnya dua tokoh penguasa Muslim, Iskandar Zulkarnain dan Nabi Yusuf, dalam masing-masing teks Carita Iskandar dan Carita Yusuf, jelas berkaitan dengan kepentingan Jawa akan hadirnya seorang penguasa yang bisa melakukan kontrol politik sepenuhnya di kerajaan. Hal ini menjadi demikian tegas dalam Kitab Usulbiyah. Dalam teks tersebut dikatakan, salah satu tujuan penting penulisan Kitab itu adalah memberi kesempurnaan raja Pakubuwana II, khususnya melalui ajaran mistik yang menjadi kandungan utama teks. Maka di sini, pertanyaan penting yang segera mengemuka adalah, bagaimana masyarakat Jawa merumuskan konsep penguasa, yang sesuai dengan sistem budaya yang tengah dibangun sebagaimana dibahas dalam tiga teks di atas?

Sebelum menjawab pertanyaan di atas, penting dijelaskan lebih dahulu beberapa hal penting berkenaan dengan sifat utama Islamisasi di Jawa. Hal ini penting, sebab rumusan konsep kekuasaan Jawa pada dasarnya banyak ditentukan moda konseptualiasi masyarakat tentang agama dan politik, yang berbasis pada pola Islamisasi yang berlangsung di wilayah tersebut. Telah diakui secara luas, perkembangan Islam di Jawa ditandai terutama oleh sikap budaya masyarakat yang menghendaki pelestarian agama pra-Islam; bahwa unsur-unsur Hindu-Budhis senantiasa menjadi substansi penting dalam kehidupan masyarakat yang telah beralih menjadi Muslim. ${ }^{8}$ Satu aspek paling menonjol dalam hal ini adalah ajaran phantheistis dan monistis Jawa, yang memandang manusia sebagai bagian dari atau berada dalam samudera eksistensi Tuhan, ${ }^{9}$ Dalam dunia Islam Jawa, doktrin inilah yang kemudian mengalami kebangkitan kembali dalam formulasi ajar- 
an Sufisme, yang memang sejalan dengan pandangan dunia Jawa di atas. Oleh karena itu, tahap awal Islamisasi Jawa, dan Nusantara umumnya, sangat didominasi ajaran Sufisme. ${ }^{10}$

Dalam konteks politik yang lebih spesifik, ajaran Sufisme inilah yang kemudian menjadi basis munculnya wacana politik yang sangat menekankan kebesaran dan kesaktian-melekatnya sifat-sifat supranatural-seorang penguasa atau raja. Ajaran Sufisme yang mengakui hubungan langsung manusia dengan Tuhan menjadi dasar legitimasi keagamaan bagi kekuasaan seorang raja, khususnya memperkuat klaim-klaim supra-natural oleh sang raja. Dan hal inilah yang berlangsung di kraton Mataram pada abad ke-18. Dalam teks-teks Jawa yang muncul saat itu, wacana politik demikian tampil dominan. Salah satu karya penting yang dibahas di bab 3 buku ini sini adalah Suluk Garwa Kencana. Teks ini mengetengahkan pemikiran Jawa tentang kekuasaan, terutama mengacu pada pribadi sang raja. Teks ini dikarang Ratu Pakubuwana pada 1730, kemungkinan besar berdasarkan teks atau tradisi serupa yang telah berkembang di Jawa sejak masa Sultan Agung. Seperti teks-teks Jawa lain, teks Suluk ini juga menempatkan Sultan Agung pada posisi sangat istimewa.

$\mathrm{Hal}$ terpenting dari pembahasan teks Suluk Garwa Kencana, seperti telah disinggung di atas, adalah filsafat kerajaan Jawa yang dikonsepsikan dalam terma-terma Sufisme Islam. Teks tersebut mencoba menghadirkan satu konsepsi Jawa tentang penguasa, yang dirumuskan melalui pribadi seorang raja yang sekaligus bertindak sebagai Sufi. Bila dalam teks sebelumnya, khususnya Kitab Usulbiyah, hanya ditegaskan pentingnya kesempurnaan raja, maka pada teks ini kesempurnaan tersebut dijelaskan secara rinci dalam bentuk penjelasanpenjelasan Sufistik. Oleh karena itu teks Suluk tersebut menekankandengan mengedepankan contoh Sultan Agung-bahwa raja harus seorang yang taat beragama dan hidup asketik, yang hanya bertujuan untuk mencapai derajat kesempurnaan melalui jalan Sufi, sehingga ia bisa berhubungan langsung dengan Ultimate Reality, Tuhan. Dan seorang raja dengan derajat kesempurnaan demikian tidak hanya memperoleh pengetahuan esoterik yang berbasis di dunia ghaib (the unseen world)-sebagai sebuah kebenaran yang sejati-tapi ia sekaligus bisa membawa dunia kerajaan yang nyata (the seen world) ke arah suasana yang dicitakan secara ideal. Jadi, raja dalam hal ini menjadi agen penyatuan dua dunia, yang dilakukan setelah melalui proses perjalanan hidup Sufistik sebelum akhirnya mencapai tingkat di mana dia bisa mencapai realitas ketuhanan. 
Rumusan penguasa Jawa ini, Raja-Sufi, penting dicatat, merupakan bentuk reproduksi atau dihidupkannya kembali khazanah budaya masa pra-Islam, Hindu-Budhis, yang diformulasikan dalam terma-terma baru yang diadopsi dari ajaran Sufisme. Pengamatan lebih seksama terhadap konsep Raja-Sufi, sebagai rumusan penguasa ideal Jawa, memberi kesan kuat bahwa ia dalam beberapa hal utama merupakan formulasi baru dari konsepsi politik Jawa pra-Islam mengenai Raja-Dewa. Di sini, raja dianggap sebagai satu-satunya perantara antara makrokosmos dan mikrokosmos, dunia ghaib dan lahir, yang mencerminkan kedudukan Tuhan di bumi; jadi raja adalah wakil (warana) Tuhan, sebagai pemegang wewenang murba wiwesa, yang berkuasa atas nama dan untuk menyelenggarakan kehendak Tuhan.10 Dalam konsep Raja Sufi pengertian Raja-Dewa ini tampak berusaha diminimalisasi, meski hal itu tidak secara langsung memiliki implikasi praktis dalam kehidupan riil kerajaan. Dalam hal ini, ketimbang menjadikan raja sebagai penjelmaan dewa di bumi, wacana politik Jawa memperkenalkan istilah baru dari tradisi Islam, khalifah Allah (kalipatullah). Sebagai khalifah Allah, raja bukan hanya tidak ditempatkan pada posisi yang semulia atau seagung sebelumnya, tapi ia justru dituntut melaksanakan ajaran-ajaran Islam. ${ }^{12}$

Dengan demikian, budaya Jawa memandang kekuasaan raja tidak hanya terbatas pada masalah-masalah sosial-politik, tapi juga meliputi masalah agama. Dalam hal terakhir ini, raja bahkan bisa menentukan sistem keberagamaan masyarakat di kerajaan. Karena itu, pembahasan selanjutnya dalam buku ini berkenaan dengan peran kerajaan dalam masalah agama, yang dinilai memiliki hubungan langsung dengan posisi raja sebagai penjaga kesesuaian mikro dan makrokosmos, dunia ghaib dan nyata. Peran raja ini dengan jelas terefleksikan dalam Serat Cabolek, ${ }^{13}$ teks sastra Jawa yang dibahas pada bab 4. Teks Serat Cabolek, berbeda dengan teks-teks Jawa lain yang telah dibahas, tidak bisa diidentifikasi baik pengarang maupun waktu penulisannya. ${ }^{14} \mathrm{Hal}$ yang pasti berkenaan teks tersebut adalah, ia menggambarkan peristiwa sejarah di kraton Kartasura, tepatnya pada April 1731 sampai Juli 1733. Begitu pula tokoh utama dalam Serat CabolekDemang Urawan, Mangkubumi, Ahmad Mutamakin, dan Ketib Anom Kudus-adalah tokoh sejarah yang hidup pada periode yang menjadi konteks cerita dalam teks tersebut. ${ }^{15}$

Sebagaimana diketahui, muatan pokok Serat Cabolek adalah drama pertentangan keagamaan khususnya dari dua orang yang masingmasing mewakili aliran keagamaan berbeda: Ahmad Mutamakin, se- 
orang Sufi dari desa Cabolek yang mengajarkan ilmu hakikat (kasunyatan), dan Ketib Anom Kudus, seorang ulama yang mewakili aliran syari'ah. Ilmu hakikat Mutamakin dianggap sesat dan membahayakan kehidupan keagamaan, sehingga kemudian mengundang kritik Ketib Anom yang mewakili para ulama. Dia selanjutnya meminta raja Jawa agar menghukum mati Mutamakin. Namun raja justru mengampuni Mutamakin, disampaikan Demang Urawan dalam satu pertemuan para ulama di kediaman Patih Danureja. Singkat cerita, Serat Cabolek selanjutnya menggambarkan perdebatan MutamakinKetib Anom tentang ajaran Sufisme yang diklaimnya berasal dari gurunya Syekh Zain di Yaman dan dari teks mistik Jawa, Serat Bima Suci atau Dewa Ruci. Di sini, perdebatan selanjutnya terfokus pada penguasaan teks mistik Jawa, yang dinilai sebagai barometer penguasaan ajaran Sufisme seperti dilakukan Mutamakin. Dan, ternyata, Mutamakin tidak bisa memahami isi utama teks miștik Jawa tersebut.

Dalam konteks pembahasan ini, hal terpenting berkenaan dengan cerita di atas adalah bahwa kontroversi keagamaan antara Mutamakin dan Ketib Anom secara langsung berhubungan dengan struktur kekuasaan Jawa, yang berpuncak pada diri raja sebagai pemegang kontrol keagamaan. Karena ajarannya yang mengganggu kehidupan keagamaan masyarakat, khususnya penolakannya terhada syari'ah, Mutamakin dianggap telah berbuat dosa kepada raja (duraka ing Ratu); dia telah menggugat hirarki sosial dan keagamaan yang dibangun berbasis ajaran Sufisme, di mana raja sebagai "pemegang monopoli pengetahuan esoterik"-sebagai Raja-Sufi-mutlak harus ditaati seluruh masyarakat kerajaan. Maka keterlibatan raja dalam persoalan keagamaan ini dinilai sebagai satu keharusan, sesuai tenggungjawabnya sebagai pemimpin agama dan politik di tanah Jawa. Jadi, bila teks Usulbiyah menekankan raja sebagai "raja pengetahuan mistik", Suluk Garwa Kencana mencatat kekuasaan raja meliputi masalah hakekat kebenaran (khak), jalan mistik (tarekat) dan hukum (sarengat), maka Serat Cabolek menandaskan raja "harus mengatur masalah agama".

Dengan demikian, jelas bahwa pertemuan Islam dan budaya Jawa terletak pada ajaran Sufisme, yang dalam bidang politik kemudian melahirkan konsep Raja-Sufi sebagai rumusan penguasa ideal Jawa. Konsep-konsep pokok politik Jawa yang berkembang saat itu terintegrasi sedemikian rupa dalam ajaran Sufisme. Meski demikian, penting diperhatikan-yang tidak dibahas dalam buku ini-bahwa perkembangan tersebut tampaknya tidak hanya berlangsung di Jawa, 
tapi juga di beberapa wilayah lain di Nusantara. Di dunia Melayu, misalnya, integrasi Sufisme dan politik ini bahkan telah muncul dalam teks-teks Melayu dari abad ke-17. Tajussalatin, ditulis sekitar 1603, adalah satu teks Melayu yang jelas-jelas mengedepankan konsep politik yang senada dengan Raja-Sufi di Jawa. ${ }^{16}$ Seperti halnya teks-teks Jawa, Tajussalatin memberi penekanan kuat pada pentingnya seorang raja ideal, yang dirumuskan dalam konsep adil. Di sini, adil tegas meng-acu pada kesempurnaan beragama seorang raja; melaksanakan perintah Allah dan mencontoh tauladan Nabi Muhammad. ${ }^{17}$ Begitu pula hal yang bernada sama juga memperoleh penekanan kuat dalam teks-teks Melayu lain, seperti Hikayat Raja-Raja Pasai dan Sejarab Melayu. Kedua teks itu memberi kesan besarnya pengaruh Sufisme dalam kehidupan bernegara di Melayu, ${ }^{18}$

Bila kita perhatikan lebih jauh, tampak bahwa dimensi Sufisme dalam budaya politik Jawa di atas-yang mendasari lahirnya RajaSufi-merupakan fenomena yang berlaku umum di Nusantara. Diletakkan pada konteks politik yang lebih spesifik, bisa dikatakan bahwa istilah "Raja-Sufi" di Jawa dan "Raja Adil" di dunia Melayu tampak banyak mengadopsi konsep "manusia sempurna" (al-insan al-kamil) dalam Sufisme seperti dirumuskan Ibn Arabi dan al-Jilli. ${ }^{19} \mathrm{Na}$ mun, penting diperhatikan, pada saat yang sama juga berlangsung satu proses di mana konsep-konsep Sufisme justru menjadi basis bagi dihidupkannya kembali gagasan manusia sempurna dalam tradisi masa pra-Islam. Kajian A.C. Milner terhadap teks-teks Melayu, dan Nusantara umumnya, menunjukkan bahwa peran para penguasa Melayu sebagai Raja Adil memperoleh basis yang kuat pada tradisi serupa masa pra-Islam, yang dikenal dengan istilah "boddhisattwa"-makhluk pencerahan Budha yang mengabdikan hidupnya untuk kebebasan rohani rakyat mereka di bumi, ${ }^{19} \mathrm{Dan}$ hal inilah tampaknya yang berlangsung di Jawa masa Pakubuwana II.

\section{Raja-Sufi dan Realpolitik}

Berkenaan dengan pemikiran politik Jawa di atas, satu pertanyaan yang wajar diangkat adalah, bagaimana Pakubuwana II, sebagai RajaSufi, menjalankan kekuasaan politiknya secara rill di kerajaan? Pertanyaan ini menjadi penting terutama untuk melihat tingkat praktis bangunan pemikiran politik Jawa sebagaimana tertuang dalam teksteks yang telah dibahas. Ini menjadi pokok pembahasan di hampir seluruh sisa bab dalam buku ini, yakni bab 7 sampai bab $10 .{ }^{21}$ Pembahasan ketiga bab terakhir ini diarahkan pada praktek-praktek politik 
Pakubuwana II, khususnya ketika dihadapkan pada perkembangan politik riil (realpolitik) di kraton Kartasura dan Jawa pada umumnya. Jadi, pembahasan berikut ini adalah untuk melihat hubungan bangunan pemikiran dengan praktek politik kraton Jawa. Dan, mungkin terpenting, sekaligus untuk mengkaji sekitar pola dan perkembangan hubungan antara Islam dan ke-Jawa-an (kejawen), di mana Islam menjadi substansi penting bagi kebangkitan budaya Jawa, sebagaimana terlihat dalam pembahasan di atas.

Di bagian awal tulisan ini dijelaskan, naiknya Pakubuwana II ke kekuasaan Mataram berlangsung dalam suasana politik yang relatif damai. Ia setidaknya terbebas dari kerusuhan politik seperti dua pendahulunya, Pakubuwana I dan Amangkurat IV, yang diwarnai masing-masing Perang Suksesi Jawa I dan II. Berberapa potensi konflik memang sudah mulai tampak, terutama oleh Pangeran Cakraningrat IV dari Madura yang keberatan berada di bawah kekuasaan Mataram; ia lebih memilih langsung di bawah kekuasaan VOC. Namun konflik ini segera bisa diselesaikan, setelah Pakubuwana IIatas nasehat ibunya, Ratu Amangkurat-menjadikan saudara perempuannya untuk dinikahi Cakraningrat. Sementara itu, perebutan pengaruh kekuasaan di kalangan para petinggi istana, seperti ditunjukkan di atas, tampaknya tidak memiliki pengaruh berarti dalam politik kraton. Akibatnya, dan ini terpenting, kekuasaan VOC di Jawa lebih terfokus di bidang ekonomi; ia tidak melakukan intervensi politik yang terlampau jauh dalam kehidupan istana.

Oleh karena itu, Pakubuwana II, tidak seperti beberapa raja Mataram sebelumnya, relatif bisa melakukan kontrol politik sepenuhnya di kerajaan. Kondisi politik ini bahkan semakin kondusif pada perkembangan selanjutnya, ketika Patih Danureja dan Pengeran Purbaya, dua elit politik terkemuka Mataram saat itu, dipenjarakan dan dibuang VOC pada 1739 karena terbukti terlibat dalam pesekongkolan anti-VOC. Maka pada periode ini Pakubuwana II bisa dengan leluasa menjalankan kekuasaannya, sesuai dengan harapan peran dari konsep Raja-Sufi seperti terdapat dalam teks-teks sastra Jawa. Ratu Pakubuwana, yang bertanggung jawab bagi lahirnya karya-karya di atas, memang berusaha mengedepankan wacana politik Jawa untuk $\mathrm{Pa}$ kubuwana II, sehingga ia bisa berkembang sebagai seorang RajaSufi. Lebih dari itu, pembuangan dua elit politik di atas selanjutnya memberi ruang lebar bagi munculnya tokoh-tokoh politik baru yang berorientasi pada penguatan Sufisme dalam kraton, khususnya Patih Natakusuma. 
Dalam banyak hal penting, praktek-praktek politik Pakubuwana II tampaknya memang memperkuat kecenderungan di atas. Satu teks sastra Jawa yang lahir dari periode ini, dan diidentifikasi dikarang (kang anggit) olehnya, Serat Wulang PakubuwanaII, banyak mengedepankan banyak gagasan yang sejalan dengan konsep Raja-Sufi di atas. Dalam pembukaan teks dikatakan, Serat Wulang dikarang dengan mengacu pada al-Qur'an dan Hadis Nabi. Teks kemudian menekankan pentingnya bahasa Arab dan Jawa dalam pemahaman agama. Ini merupakan ungkapan simbolis perpaduan Islam dan budaya Jawa, yang juga menjadi perhatian penting teks-teks sastra Jawa sebelumnya, khususnya Serat Cabolek. Lebih dari itu, Serat Wulang selanjutnya memberi nasehat-nasehat keagamaan dalam kerangka Islam Jawa. Ia menganjurkan pelaksanaan rukun Islam, taat beribadah, hidup berakhlak dan kerja keras; juga dengan panjang lebar mengingatkan Muslim Jawa akan bahaya degradasi moral akibat kebiasaan menghisap candu; dan ia juga mengajarkan banyak hal tentang mistisisme Islam yang sangat dikenal dalam teks-teks sastra Jawa. Hal terpenting, Serat Wulang memberi perhatian spesifik di bidang politik Jawa, khususnya kebesaran raja dalam struktur kekuasaan. Di sini, teks tersebut menempatkan raja Jawa berada di bawah Tuhan dan Nabi sebagai pemegang otoritas tertinggi yang wajib diikuti.

Sejalan dengan itu, Pakubuwana II tercatat melakukan tindakantindakan politik yang mencerminkan upayanya mempraktekkan ajaran Islam dalam kehidupan kraton. Dia misalnya telah menghukum mati seorang anak Penghulu bersama-sama dengan seorang selir raja karena keduanya diketahui melakukan hubungan seksual di luar nikah. Kasus ini kemudian melibarkan seluruh keluarga penghulu, yang membiarkan hal itu terjadi dengan sepengetahuannya. Raja memerintahkan untuk membuang semua keluarga penghulu. Sejak saat itu, pada sekitar 1739, posisi penghulu digantikan seorang ulama bernama Ketib Anom, yang sangat mungkin adalah nama yang tercatat dalam Serat Cabolek. Selain itu, Pakubuwana II juga tercatat melarang keras perbuatan-perbuatan seksual menyimpang, khususnya homoseksual yang tampak mulai dilakukan elit politik kerajaan. Bahkan, meski kurang didukung fakta yang memadai, Pakubuwana II sendiri konon punya kecenderungan melakukan homoseksual.

Dua kebijakan di atas-di samping banyak kebijakan lain-jelas merupakan wujud hasrat Pakubuwana II yang besar dalam menciptakan pemerintahan yang bersih di lingkungan kerajaan Mataram. $\mathrm{Hal}$ ini tentu saja harus dipahami sebagai bagian penting dari prak- 
tek-praktek politik seorang Raja-Sufi, yang menghendaki dilaksanakannya ajaran Islam di kerajaan. Dalam banyak hal penting, Pakubuwana II tampaknya berhasil mewujudkan harapan peran yang dinisbahkannya secara kultural sebagai seorang penguasa ideal Jawa, Raja Sufi. Setidaknya sampai pada 1940, Pakubuwana II tidak dihadapkan pada tantangan politik yang berarti. Dia justru memberi banyak dukungan politik bagi kebangkitan Islam Jawa. Jadi pada periode ini, pertentangan antara Islam dan Jawa, yang kerap dipahami banyak kalangan, lenyap dari wacana intelektual. Lebih dari itu, keharmonisan Islam-Jawa bahkan menjadi sedemikian jelas dalam praktekpraktek politik riil di kerajaan. Bangunan Islam Jawa ideal ini di antaranya terekspresikan dalam Serat Cabolek. Dalam teks tersebut, karya-karya sastra Jawa kuno dari masa pra-Islam-seperti Serat Bima Suci, Arjunawiwaha, dan Ramayana-diakui sebagai karya Sufisme, sebanding karya-karya serupa yang ditulis para sarjana Muslim.

Namun tidak demikian halnya dengan perkembangan kerajaan periode setelah 1740. Beberapa persoalan politik, seperti akan djelaskan secara rinci, mulai muncul ke permukaan serta memperlihatkan gejala yang bisa membawa pada disintegrasi kerajaan. Persoalan ini berawal dari sikap politik Cakraningrat IV di Madura, yang lagi-lagi memperlihatkan keberatannya berada di bawah kekuasaan Mataram. Lebih dari itu, ia mulai membangun kekuasaan politik di ujung timur Jawa, bersamaan dengan politiknya di bidang budaya yang secara terang-terangan mengadopsi tradisi kerajaan Bali. Data-data sejarah yang berhasil dihimpun menunjukkan, Cakraningrat IV menolak datang pada acara grebeg maulud, satu festival politik-keagamaan yang sangat penting di kraton Jawa. Ia kerap kali hanya mengutus istri dan anak-anaknya. Perkembangan ini tentu saja menjadi persoalan serius bagi Pakubuwana II. Namun, pada saat yang sama, ia tampaknya tidak bisa berbuat apa-apa. Sebab, kondisi geografis Madura di luar kemampuan ekspedisi militer kerajaan, di samping, dan terpenting, VOC tampak bersikap netral dalam kasus ini.

Persoalan politik di atas-selain persoalan-persoalan lain, termasuk kerugian ekonomi yang diderita VOC-akhirnya berkembang menjadi krisis politik besar yang sangat menentukan nasib kraton Jawa di bawah Pakubuwana II. Krisis ini terjadi mulai pada akhir 1740 , ketika VOC melakukan pembunuhan besar-besaran terhadap masyarakat Cina di Jawa, yang saat itu jumlahnya semakin bertambah. Peristiwa ini berakar pada sikap saling curiga yang tertanam sejak lama antara VOC dengan masyarakat Cina di Batavia, yang 
menguasai banyak kegiatan ekonomi. Pihak VOC mengira bahwa orang-orang Cina tengah merencanakan sebuah pemberontakan, sementara pihak Cina berkesimpulan bahwa VOC akan mengusir mereka dari tanah Jawa, khususnya Batavia. Sikap saling curiga ini akhirnya meletus menjadi sebuah pembantaian terhadap orang-orang Cina pada 9 Oktober. Tercatat sekitar 10.000 orang Cina tewas dibunuh pihak VOC, disertai perampokan serta pembakaran terhadap perkampungan mereka.

Periatiwa ini, meski tidak berhubungan langsung dengan kraton, memiliki imbas politik sangat kuat pada perkembangan politik Mataram dan akhirnya perjalanan kekuasaan Pakubuwana II. Konflik keras VOC-Cina ini selanjutnya menghadapkan Pakubuwana II pada keharusan untuk memilih antara memihak kepada orang-orang Cina, yang saat itu tengah melakukan pembalasan dengan menguasai pospos VOC di Jawa, atau mendukung VOC. Pilihan terakhir ini, yang disuarakan para penguasa daerah pesisir Jawa, rencananya dilakukan saat VOC menghadapi kesulitan, sehingga bantuan yang diberikan bisa digunakan sebagai alasan untuk meninjau kembali perjanjian Jawa-VOC sebelumnya yang dirasakan cukup memberatkan.

Dalam situasi ini, Pakubuwana II memilih melawan VOC dengan membantu Cina. Pilihan ini sesuai dengan aspirasi kelompok politik di istana yang dipimpin Patih Natakusuma, Maka Mataram segera mengirim pasukan dan artileri ke Semarang guna mendukung orangorang Cina yang sedang mengadakan pengepungan di kantor pusat VOC di wilayah itu. Dalam peristiwa ini, November 1741, tercatat setidaknya 20.000 orang Jawa membantu orang-orang Cina yang berjumlah sekitar 3.500 orang. Sikap politik Mataram ini bahkan semakin jelas ketika tentara kerajaan menyerang pos garnisun VOC di Kartasura. Peristiwa ini, juga terjadi pada 1741, telah menewaskan komandannya, Kapten Johannes van Velsen. Bagi VOC, penyerangan ini merupakan bukti terakhir bahwa Pakubuwana II di Mataram secara terbuka memutuskan hubungan dengan VOC.

Sikap politik Pakubuwana II di atas ternyata membawa konsekuensi yang tidak menguntungkan bagi Mataram. Dalam situasi sulit, VOC kemudian berpaling kepada satu kekuatan militer yang memang masih setia, yakni Cakrangingrat IV di Madura. Bagi Cakraningrat, hal ini tentu saja merupakan kesempatan yang memang ditunggu-tunggu. Maka ia segera mengirim bantuan kepada VOC, dengan syarat ia diizinkan lepas dari Kartasura dan memerintah secara merdeka di bawah VOC langsung. Setelah VOC menyetujui semua syarat yang 
diajukan, Cakraningrat segera mengirim bantuan pasukan dalam jumlah besar ke Semarang. Aliansi Madura-VOC inilah yang kemudian berakibat buruk bagi Mataram. VOC segera melakukan serangan dan akhirnya menguasai kembali Semarang. Pada akhir 1741 dan awal 1742, hampir semua pos VOC yang sempat dikuasai Cina berhasil direbut kembali. Kemenangan VOC ini kemudian tidak saja menjadikan raja sebagai pihak yang kalah perang, sehingga dia harus memohon ampun VOC untuk bisa tetap berkuasa. Tetapi, lebih dari itu, Pakubuwana II sekarang dihadapkan pada persoalan internal kerajaan, terutama pihak yang tidak puas terhadap kebijakannya. Sementara itu, Cakraningrat IV semakin memperluas kekuasannya di belahan timur Jawa.

Sebelum membahas lebih jauh implikasi politik dari kondisi di atas, penting dijelaskan di sini sikap politik-keagamaan Pakubuwana II, khususnya dalam kaitan dengan nama yang disandangnya sebagai Raja-Sufi, Dari sumber-sumber sejarah yang ada, bisa dikatakan bahwa sikap Pakubuwana II mungkin bisa disebut "mengecewakan". Dihadapkan pada situasi politik yang demikian gawat, Pakubuwana II justru semakin terlena dengan pemikiran mistisme spekulatif. $\mathrm{Hal}$ ini bisa dilihat setidaknya dari dua naskah Sufi yang diidentifikasi berasal dari periode kekacauan politik ini: Kitab Daka dan Kitab Fatahurrabman. Sebagaimana karya-karya Sufisme Islam Jawa yang telah dibahas di atas, kedua teks ini juga mengetengahkan pemikiran yang menekankan pentingnya penyatuan manusia-Tuhan (manunggaling Kawula-Gusti), yang dilakukan dalam kerangka jalan mistik yang sudah dikenal luas. Di sini tidak akan dibahas secara rinci kandungan dua teks tadi. Hal yang perlu dicatat adalah, kondisi yang tengah berlaku di Mataram saat itu tampaknya menghendaki kebijakan politik Pakubuwana II yang lebih dari sekedar pembacaan dzikir untuk mencapai kesatuan dengan zat Tuhan yang bersifat ekstatik.

Namun hal demikianlah yang justeru terus berlangsung. Pakubuwana II semakin tidak populer di kalangan masyarakat kerajaan. Pengampunan oleh VOC atas kesalahannya yang telah mendukung pihak Cina, yang berlanjut dengan pemulihan kembali kerjasama JawaVOC, semakin memperbesar sentimen ketidaksukaan sebagian masyarakat terhadap raja. Hal ini kemudian mengakibatkan lahirnya pemberontakan masyarakat Jawa, yang didukung orang-orang Cina. Pada 1742, mereka bahkan mengangkat seorang penguasa baru, Raden Mas Gerendi, yang kemudian dikenal Sunan Kuning. Dia adalah cucu Amangkurat III, yang sebelumnya dibuang VOC. Pemberon- 
takan ini mencapai puncaknya pada Juni 1742 , ketika mereka berhasil merebut kraton Kartasura. Pakubuwana II berhasil melarikan diri ke arah timur, bersama-sama dengan pasukan VOC yang berjumlah sangat kecil di bawah pimpinan van Hohendorff. Dalam masa pengasingan ini, Pakubuwana II sekali lagi menyatakan harapannya atas bantuan VOC. Dia sekaligus bersedia membuat perjanjian baru sesuai dengan kehendak VOC.

Pendudukan Sunan Kuning atas kraton Kartasura tidak bertahan lama. VOC tidak bersedia memberi dukungan politik, terutama karena ia dibantu banyak orang Cina, musuh utamanya di tanah Jawa. Maka pada Desember 1742, ia berhasil dipukul mundur pasukan Cakraningrat IV, yang saat itu telah mencapai wilayah sekitar kraton Mataram. Kini kraton Kartasura diduduki Cakraningrat IV, yang berlangsung sampai November 1743. Didesak kekuatan VOC, Cakraningrat IV akhirnya bersedia mengembalikan kraton kepada $\mathrm{Pa}$ kubuwana II. Di sini penting dijelaskan bahwa VOC memang lebih bersedia bekerjasama dengan Pakubuwana II, sebab hal itu lebih menguntungkan bagi kepentingan VOC di Jawa. Dalam sejarah dinasti Mataram, Pakubuwana II bisa disebut sebagai penguasa paling lemah, sehingga bisa memberi kesempatan VOC untuk berperan lebih besar baik di dalam kraton maupun di Jawa umumnya. Demikianlah, Pakubuwana II kembali berkuasa sebagai raja Mataram, dengan tentu saja bersedia mengakui perjanjian baru yang ditawarkan yang jelas semakin menguntungkan VOC.

Namun demikian, naiknya kembali Pakubuwana II ternyata bukan akhir dari kemelut berkepanjangan yang melanda kraton Mataram. Di wilayah timur Jawa, Cakraningrat IV semakin meningkatkan kekuatan politiknya. Ia menjalin hubungan dengan keluarga yang berkuasa di Surabaya dan dengan keluarga Surapati. Dia bahkan mulai menghentikan pembayaran beras dan cukai pelabuhan dari Jawa timur kepada VOC. Sementara itu, pada saat yang sama, Pakubuwana II juga dihadapkan pada sejumlah pemberontakan, khususnya yang dilakukan R. Mas Said, Kondisi ini kemudian memaksa Pakubuwana II memutuskan meninggalkan Kartasura. Ia membangun istana baru yang terletak di sekitar 12 kilometer ke arah timur, yang kemudian dikenal sebagai Surakarta. Istana baru ini selesai dibangun pada 1745, dan Pakubuwana II resmi berpindah setahun kemudian, pada seki$\operatorname{tar} 1746$.

Keputusan Pakubuwana II ini pun tidak memecahkan persoalan kerajaan. Tidak lama setelah Pakubuwana II meninggal dan diganti- 
kan putranya, Pakubuwana III (1749-1788), Pangeran Mangkubumi melancarkan pemberontakan pada 1746 , sehingga meletuslah Perang Suksesi Jawa III (1746-1757). Perang ini berakhir dengan diakuinya kekuasaan Mangkubumi di Yogyakarta, Pada 13 Pebruari 1755, melalui perjanjian Giyanti, VOC mengakui Mangkubumi sebagai Sultan Hamengkubuwana I, penguasa separoh wilayah Jawa Tengah. Maka sejak saat itu, kerajaan Mataram pecah menjadi dua kerajaan, masingmasing di Surakarta yang dipimpin Pakubuwana III dan di Yogyakarta di bawah pimpinan Hamengkubuwana I. Meski demikian, pemberontakan masih terus dilakukan Raden Mas Said, yang akhirnya berhasil diselesaikan melalui perundingan. Sebagai imbalanya, ia diangkat menjadi Pangeran Adipati Mangkunegara I (1757-1795), dan akhirnya secara resmi diakui sebagai satu kerajaan yang merdeka dari Surakarta dan Yogyakarta.

Demikianlah, sampai pada periode ini kerajaan Mataram pecah menjadi tiga kerajaan yang merdeka satu sama lain, dan Pakubuwana II adalah raja terakhir yang masih menyaksikan keutuhan Mataram. Dalam kaitan ini, penting dijelaskan beberapa hal khususnya berkenaan dengan masa-masa akhir kekuasaan Pakubuwana II di kraton Mataram. Hal ini penting terutama berkaitan dengan label RajaSufi yang diembannya. Di atas telah dikatakan bahwa kecenderungan Sufisme dalam diri Pakubuwana II, dan lingkungan kraton pada umumnya, tampak semakin kuat bahkan ketika kerajaan dihadapkan pada persoalan realpolitik yang semakin kompleks. Dari sini, masalah selanjutnya muncul terutama ketika kerajaan memang memasuki masa kekacauan politik dengan dikuasainya kraton oleh kalangan pemberontak, yakni Sunan Kuning dan Cakraningrat IV. Apa yang sesungguhnya berlangsung pada diri seorang Raja-Sufi, ketika di harus melarikan diri dari kraton dengan hanya ditemani segelintir pasukan Jawa dan VOC?

Berdasarkan sumber-sumber sejarah, khususnya Babad Surakarta, sumber Jawa yang memang banyak dikutip dalam buku ini, bisa dikatakan bahwa masa pelarian ini memang menjadi periode penting dan menentukan dalam perjalanan akhir kekuasaan Pakubuwana II. Selama pelarian, ia diberitakan memperoleh pengalaman-pengalaman spiritual yang kemudian mempengaruhi pandangan politik-keagamaan, dan tentu saja praktek-praktek politik pada masa-masa akhir kekuasaannya. Salah satu pengalaman paling dramatis dalam hal ini adalah pertemuannya dengan roh Sunan Lawu ketika dia berada di desa Sawo. Dalam tradisi Jawa, Sunan Lawu dianggap sebagai sumber kekuatan 
magis seperti halnya Ratu Pantai Selatan; kraton Jawa masih memberikan sesajen untuk kedua sumber kakuatan tersebut, bahkan hingga masa belakangan ini. Pakubuwana II diceritakan meminta bantuan immaterial (Hyang Sukma) dengan melakukan praktek-praktek asketis. Bersama dengan para pengikutnya, dia tidur di udara terbuka, mengurangi makan, dan menghabiskan waktu dengan diskusi masalah keagamaan.

Pengalaman spiritual ini tampak memberikan nuansa yang berbeda dengan masa sebelumnya. Di sini, sumber kekuatan magis Pakubuwana II lebih digambarkan sebagai makhluk spiritual yang jelas-jelas berakar dalam budaya Jawa pra-Islam. Dalam cerita legenda Jawa, Sunan Lawu dipercaya sebagai penguasa terakhir kerajaan Majapahit yang diusir para penakluk Muslim, Ia kemudian menjadi roh kekuatan yang berdomisili di Gunung Lawu. Maka sejumlah pantangan diyakini tidak boleh dilakukan ketika mendaki gunung tersebut, khususnya menyebut nama Allah. Dan, seperti halnya terhadap Ratu Pantai Selatan, juga dilarang memakai pakaian poleng yang berwarna hijau. Dengan demikin, jelas bahwa Sunan Gunung Lawu, seperti halnya Ratu Pantai Selatan, merupakan sumber-sumber kekuatan magis $\mathrm{Pa}$ kubuwana II yang diasosiasikan dengan budaya Jawa pra-Islam. $\mathrm{Hal}$ ini selanjutnya juga tampak pada pertemuannya dengan seorang suci di Gunung Wilis, Embahan Sakondha. Seperti halnya Suna Lawu, Embahan Sakondha digambarkan sebagai seorang petapa suci (sang palinggib), yang diminta nasehat oleh Pakubuwana II dalam usahanya mengembalikan kerajaan Mataram yang tengah berada di tangan pemberontak.

Dari dua pengalaman spiritual ini, di samping pengalaman spiritual lain, jelas memberi bukti kuat mulai berlakunya politik-keagamaan baru oleh Pakubuwana II yang lebih berbasis pada budaya praIslam, terutama jika dibanding masa sebelumnya. Dalam hal ini, revivalisme warisan Hindu-Budhis tampak membentuk wacana dominan dalam perkembangan pemikiran politik-keagamaan Jawa. Kecenderungan ini memang tidak bisa dilihat terlepas dari krisis politik dahsyat yang melanda kraton Mataram. Pakubuwana II, dengan Raja-Sufi yang diembannya, bisa dikatakan tidak berhasil memberikan respon yang dibutuhkan realpolitik di tanah Jawa saat itu. Lebih dari itu, intervensi VOC dalam pemulihan kekuasaannya memang membawa konsekuensi penting di kehidupan keagamaan kraton. $\mathrm{Pa}$ kubuwana II harus mengusir sejumlah elit politik yang terbukti terlibat dalam gerakan anti-VOC, yang secara kebetulan adalah mereka 
yang memiliki komitmen tinggi terhadap Islam, khususnya dengan Raja-Sufi ini. Di antaranya yang terpenting Patih Natakusuma, yang kemudian ditangkap dan dipenjarakan VOC.

Oleh karena itu, bisa dipahami bahwa di akhir masa kekuasaannya, Pakubuwana II lebih tertarik terhadap praktek-praktek keagamaan pra-Islam. Sufisme Islam dilihat, dan memang terbukti, tidak mampu melindungi dirinya dari huru-hara politik. Ia tidak lagi hadir sebagai kekuatan supranatural (the unseen world) yang memberi aura kebesaran dan melepaskannya dari rongrongan ideologi dan politik yang berlangsung dalam di kerajaan (the seen world). Maka, dengan sendirinya, peran raja sebagai perantara dua dunia, sebagai Raja-Sufi, tidak lagi berjalan secara efektif. Kekuatan riil kekuasaan Pakubuwana II kini diperoleh, selain dari Ratu Pantai Selatan, juga dari barisan tentara VOC di kraton Surakarta. Karena itu, juga dari titik pandang inilah selanjutnya bisa dipahami bahwa menjelang meninggalnya, $\mathrm{Pa}$ kubuwana II justru menghendaki kerajaan Mataram dipimpin Baron van Hohendorff, gubernur VOC untuk wilayah pesisir timur laut Jawa.

\section{Penutup}

Berdasarkan semua penjelasan di atas, bisa dikatakan di sini bahwa abad ke-18 dalam sejarah Nusantara memang ditandai kebangkitan budaya Islam Jawa. Sejumlah besar teks sastra Jawa, khususnya berisi pembahasan masalah politik-keagamaan Jawa, berasal dari periode ini. Pakubuwana II, penguasa Mataram saat itu, telah berperan penting dalam proses kebangkitan budaya Jawa. Bersama elit politik kerajaan, khususnya Ratu Pakubuwana, ia memberi dukungan politik bagi kebangkitan budaya dan sastra Jawa. Bahkan, di atas segalanya, kebangkitan budaya Jawa ini memberikan bukti kuat besarnya pengaruh Islam. Kebangkitan budaya ini berlangsung di tengah suasana di mana Islam tengah mengalami proses pelembagaan secara intensif di tengah masyarakat pada abad ke-18. Satu periode dalam sejarah Jawa yang selama ini cukup terabaikan dari perhatian para sarjana, khususnya yang melakukan kajian tentang Jawa dan Indonesia umumnya.

Buku ini memberi kontribusi sangat berarti, melampaui keberhasilan luar bisa mengungkap periode gelap dalam sejarah tanah Jawa. Ditulis seorang sejarawan kenamaan, buku ini sekaligus mengetengahkan satu pola pembahasan yang berbeda dari kajian-kajian sebelumnya. Hal terpenting dicatat di sini, buku ini menghadirkan waca- 
na pemikiran politik-keagamaan Jawa sebagai bagian inheren dari praktek-praktek politik penguasa Jawa saat itu, khususnya Pakubuwana II. Perumusan dan pelembagaan Islam Jawa, khususnya Sufisme, dilihat sebagai wacana politik-keagamaan kraton yang, memang, seperti masa pra-Islam, berperan sebagai pusat reproduksi makna keagamaan dan budaya Jawa. Dari sinilah Raja-Sufi, salah wujud utama perumusan Islam Jawa di bidang politik, sekaligus berfungsi sebagai ideologi kerajaan Mataram Jawa masa Pakubuwana II.

Maka dalam beberapa segi penting, buku ini bisa dikatakan mewakili kecenderungan baru kajian Islam Indonesia yang berkembang belakangan, yang disebur Mark Woodward sebagai "paradigma yang berpusat pada Islam" (Islam-centered paradigm)..$^{22}$ Dalam buku ini, Islam ditempatkan pada posisi penting dalam budaya Jawa. Tidak seperti karya-karya sebelumnya, khususnya yang cenderung menempatkan Islam bertentangan dengan budaya Jawa. Namun, pada saat yang sama, harus pula diingat bahwa pandangan Ricklefs dalam buku ini adalah argumen seorang sejarawan. Ia tampak berusaha melepaskan diri dari kecenderungan membuat satu konstruksi tertentu yang kemudian dianggap sebagai satu "rumusan permanen" tentang Islam Jawa atau politik Jawa. Buku ini justru menempatkan pemikiran politik dan Islam Jawa dalam perkembangan sejarah, sehingga perubahan dan perkembangan senantiasa memperoleh pembahasan penting. Maka di akhir pembahasan buku ini, ditekankan bahwa hubungan harmonis Islam-Jawa, yang menjadi basis bagi perkembangan politik-keagamaan yang dibahas, mensyaratkan prasyarat lain yang berakar pada kondisi politik Jawa. Dalam hal ini, Ricklefs mengatakan bahwa memasuki abad ke-19, ketika kekuatan kolonialisme telah menciptakan satu kelompok sosial priyayi, hubungan Islam-Jawa bukan saja tidak harmonis tapi justru telah diwarnai konflik dan pertentangan tajam. ${ }^{2 ;}$

Dalam konteks ini, buku ini berbeda misalnya dari karya Soemarsaid Moertono yang dikutip di atas, yang cenderung memberi gambaran sinkronis tentang budaya politik Jawa. Begitu pula buku in berbeda dari beberapa karya penting tentang Islam Jawa, khususnya yang berangkat dari kajian terhadap teks-teks Jawa tertentu, seperti Soebardi tentang Serat Cabolek, Peter Carey tentang Babad Dipanegara, serta beberapa karya lain. Lebih dari itu, buku ini mengedepankan kesimpulan berbeda tentang Islam Jawa, khususnya oleh kalangan orientalis yang cenderung menempatkan Islam bertentangan secara permanen dengan budaya Jawa. Dan, terakhir, hal yang juga 
sangat penting dengan kehadiran buku ini adalah, ia telah menghadirkan sebuah karya sejarah yang dilakukan secara sungguh-sungguh. Kemampuan penulis mengakses sumber-sumber primer, baik dari naskah Jawa maupun arsip-arsip VOC, merupakan salah satu bukti dari kesungguhan seorang Ricklefs. Dan sekaligus menjadi salah satu kekuatan utama buku ini. 


\section{Catatan}

1. Lihat, misalnya, Soebardi, The Book of Cabolek, A Critical Edition with Introduc. tion, Translation and Notes; a Contribution to the Study of the Javanese Mystical Tradition, (The Hague: Martinus Nijhoff, 1975), Dalam buku ini, Soebardi mencatat sejumlah teks sastra Jawa yang lahir dari periode ini, yang ditulis Yasadipura I (1729-1803): seperti Serat Rama, Serat Menak, dan Serat Ambiya. Seperti halnya Scrat Cabolek, teks-teks sasura Jawa tersebut mengandung banyak unsur Islam. Untuk kasus teks yang lain, lihat misalnya kajian Simuh, Mistik Islam Kejawen: Siudi Terhadap Serat Wirid Hidayat Jati, (Jakarta: UI-Press, 1988); lihat pula Karel Steebrink, Beberapa Aspek tentang Islam di Indonesia Abad ke-19, (Jakarta: Bulan Bintang, 1984).

2. Untuk pembahasan rinci gerakan neo-Sufisme ini, lihat Azyumardi Azra, "The Transmission of Islamic Reformism to the Indonesia; Networks of Midlle Eastern and Malay-Indonesian Ulama in the Seventeenth and Eighteenth Centuries", Ph.D. disseratation, Columbia University, 1992.

Penting dijelaskan, istilah neo-Sufisme dalam konteks kajian ini tampaknya harus digunakan secara sangat hati-hati. Bukti-bukti tentang perkembangan Islam di Jawa lebih memperlihatkan berlakunya Islam Sufi, model Islam yang justru menjadi sasaran kritik keras kalangan ulama neo-Sufis, kbususnya di dunia Melayu, sebagaimana ditunjukkan Azyumardi Azra.Di Jawa, seperti dijelaskan secara rinci di buku imi, neo-Sufisme yang puritan tampaknya tidak memperoleh tempat yang kuat di masyarakat Jawa, khususnya di lingkungan kraton Mataram masa Pakubuwana II ini.

3. Lihat Siti Chamamah Soeratno, Hikatyat Iskandar Zulkarnain: Analists Resepsi, Jakarta: Balai Pustakà, 1991.

4. Penting dijelaskan, cerita lskandar Zulkkarnain pada dasarnya berasal dari tradisi Yunani yang sudah diadopsi oleh kaum Muslim. Cerita tersebut didasarkan pada karya sastra Yunani klasik, Pseudo Callisthenes, ditulis sekitar 1200 SM. Dalam karya ini, yang kemudian diterjemahkan ke dalam beerbagai bahasa Eropa, Iskandar Zulkarnain (Alexander the Great) digambarkan sebagai seorang penguasa penguasa besar Yunani-Macedonia, yang telah berjasa membawa budaya Helenisme memperoleh supremasi di dunia. Penjelasan tentang hal ini bisa dibaca dalam G. Carey, The Medieval Alexander, (Cambridge: Cambridge University Press, 1967).

5. Lihat misalnya A. Reid, Southeast Asta in the Age of Commerce, 1450-1680, (New Haven and London: Yale University Press, 1993), vol 2, kbususnya bab tentang "revolusi keagamaan".

6. Siti Chamamah mencatat bahwa hampir semua teks Melayu memuat cerita tentang tokoh Isklandar Zulkarnain, seperti Misa Melayu, Hikayat Palembang, Hikayat Aceh, dan sebagainya. Lihat, Hikayat, hal. 146-162.

7. Lihat R.O. Winstedt, (ed), "Sejarah Melayu or Malay Annals",JMBR.AS, 16 (1938), h. 1-222; libat pula J.J. Ras, Hikayat Bandjar, (The Hague: Martinus Nijhoff, 1968), h. 129.

8. Lihat misalnya Taufik Abdullah, "Islam and the Formarion of Tradition in the Malay World", Itinerario, 13 (1989), h. 17-36; juga artikelnya yang lain, "Islam dan Pembentukan Tradisi di Asia Tenggara: Sebuah Perbandingan", dalam Taufik Abdullah dan Sharon Siddique, (d.), Tradisi dan Kebangkitan Islam di Asia Tenggara, (Jakarta: LP3ES, 1989), h. 58-99. Dalam artikelnya ini, Taufik Abdullah berpendapat bahwa Islamisasi di Jawa ditandai perkembangan ke arah pemben- 
tukan corak "tradisi dialog", yang berbeda dengan dunia Melayu yang memperlihatkan corak "tradisi integratif", di mana Islam diterima menjadi bagian inheren dari pembentukan sistem budaya .

9. Lihat P.J. Zoetmulder, Manunggaling Kawula Gusti: Pantheisme dan Monisme dan Sastra Saluk Jawa, (Jakarta: Gramedia, 1990).

10. Lihat, misalnya, A.H. Johns, "Sufism as a Category in Indonesia Literature and History", JSEAH, 2 (1961), h, 10-23; M.C. Ricklefs, "Six Centuries of Islamization in Java", dalam Nehemia Levtzion, (ed.), Conversion to Islam, (New York: Holmes \& Mier Publisher, 1979), ; dan juga G.W. J. Drewes, "Indonesia: Mysticism and Activism", dalam G.E. von Grunebaum, (ed.), Unity and Variety in Muslim Civilization, (Chicago: Chicago University Press, 1955).

11. Untuk penjelasan rinci mengenai hal ini, lihat $\mathrm{R}$. Heine-Geldern, "Conception of State and Kingship in Southeast Asia", The Far Eastern Quatierly, 2 (1942); juga Soemarsaid Moertono, Negara dan Usaha Bina-Negara di Jawa Masa Lam. pall, (Jakarta: Yayasan Obor, 1985), khususnya bab 2.

12. Soemarsaid Moertono, Negara, h. 34-35. Penting dijelaskan, dalam politik Melayu penegasan tentang hal ini bahkan sangat jelas dalam teks-teks Melayu seperti Sejarah Melayu dan Hikayat Raja-Raja Pasai. Dalam kedua teks tersebut, dikatakan bahwa raja berkewajiban menerapkan hukum Islam, syariah, di masyarakat kerajaan. Lihat misalnya, Hussin Mutalib, "Islamic Malay polity in Southeast Asia", dalam Mohd. Taib Osman, (ed.), Islamic Civitization in the Malay World, (Kuala Lumpur dan Istambul: Dewan Bahasa dan Pustaka dan The Research Centre for Islamic History, Culture and Art, 1997), h. 6-13.

13. S. Soebardi, The Book of Cabolek:

14. Penting dijelaskan, Ricklefs dalam hal ini tidak sependapat dengan Soebardi yang berkesimpulan bahwa Serat Cabolek adalah karya Yasadipura I (1729-1803), seorang pujangga kraton yang hidup pada masa Pakubuwana IV (1788-1820). Argumen Ricklefs dalam bantahannya terhadap pendapat Soébardi ini bisa dibaca di hal, 127-129.

15. Ricklefs di sini lagi-lagi berseberangan dengan Soebardi, yang berpendapat bahwa tokoh-tokoh utama dalam Serat Cabolek adalah fiktif, semata-mata produk imajinasi sastrawan Yasadipura I. Ricklefs dalam hal ini mencatat empat tokoh penting dalam Serat Cabolek, yang bisa diidentifikasi sebagai hudup di masa $\mathrm{Pa}$ kubuwana II.

16. Teks ini telah diedit dan ditransliterasi oleh Jumsari Jusuf, Taftssalatin, (Jakarta: Departemen Pendidikan dan Kebudayaan, 1979). Untuk edisi lebih panjang dilakukan Khalid Hussain, Bukhari Al-Jathari, Taj ws-Salatin, (Kuala Lumpur: Dewan Bahasa dan Pustaka, 1966). Untuk kajian terhadap teks ini, di antaranya lihat Taufik Abdullah, "The Formation of Political Tradition in the Malay World", dalam A Reid, (ed.), The Making of an Islamic Political Discourse in South. east Asia, (Monash: Monash Paper on Southeast Asia, 1993), hal. 35-58.

17. Tajussalatin, Jusuf, hal. 40-41; Hussain, hal. 69.

18. Tentang kedua teks tersebut, lihat A.H. Hill, (ed.), Hikayat Raja-Raja Pasai", JMBRAS, 33 (1960), h. 1-111; R.O. Winstedt, "The Malay Annals".

19. Kasus kajian tentang hal ini bisa dilihat misalnya di kerajaan Aceh oleh L.F. Brakel, "State and Statecraft in 17 th Century Aceh", dalam A. Reid, (ed.), PreColonial State Systems in Southeast Asia, (Kuala Lumpur: Monograph of the Malaysian Branch of the Royal Asiatic Society, 1975). Untuk kasus di kesultanan Butin di Sulawesi bisa dibaca dalam Abd Rahim Yunus, Posisi Tasarouf dalam 
Sistem Kesultanan Buton pada Abad ke-19, (Jakarta: INIS, 1995).

20. Lihat A.C. Milner, "Islam and Muslim State", dalam M.B. Hooker, (ed.), Islam in Southeast Asia, (Leiden: E.J. Brill 1984), h. 23-49; untuk edisi Indonesianya, "Islam dan Negara Muslim", dalam Azyumardi Azra, (ed.), Perspektif Islam di Asia Tenggara, (Jakarta: Yayasan Obor, 1989), h. 145-1980.

21. Mark R. Woodward, (ed.), Towewrds a New Paradigm: Recent Development in Indonesian Islamic Thought, (Temple, Arizona: Arizona State University Press, 1996); Lihat pula Ihsan Ali-Fauzi, "Paradigma Baru Islam di Indonesia", Studia Islamika, Vol.4, No. 3 (1997), h. 219-246.

22. Pembahasan berikut ini disarikan dari tiga bab terakhir buku ini, di samping karya Ricklefs yang lain, Modern Indonesia History, khususnya bab bab 2 dan 3 ,

23. Di sini Ricklefs, seperti diakuinya sendiri, sejalan dengan pendapar Peter Carey, khususnya dalam karyanya, "Satria and Santri; Some Notes on the Relationship between Dipanegara's Kraton and Religious Supporters during the Java War (1825-1830)", dalam Ibrahim Alfian at al (ed.), Dari Babad Sampai Hikayat Hingga Sejarah Kritis, (Yogyakarta: UGM-Press, 1987), h. 271-318.

Jajat Burhanuddin adalah dosen pada Fakultas Adab IAIN Syarif Hi. dayatullah, Jakarta 